\title{
PEREMPUAN DALAM NOVEL KHADIJAH: KETIKA RAHASIA MIM TESINGKAP KARYA SIBEL ERASLAN (ANALISIS GENDER DAN AGENSI PEREMPUAN)
}

\author{
${ }^{1}$ Eka Francisca Fitri Agustin dan ${ }^{2}$ Endrika Widdia Putri \\ ${ }^{1}$ Universitas Negeri Yogyakarta \\ ${ }^{2}$ Universitas Islam Negeri Sunan Kalijaga Yogyakarta \\ ${ }^{1}$ ekaagustin504@gmail.com \\ ²endrikawiddiaputri@yahoo.co.id
}

\section{Abstract}

This article describes the gender construction in the novel Khadijah: Ketika Rahasia Mim Tersingkap by Sibel Eraslan. This novel mentioned about gender construction in Jahiliyyah period which was attached and burden to women. Women in this novel are discriminated figures which contrast to men. However, in that situation, Khadijah was present as an agent of change whose gave women a new color, better and classy life. So, more specifically this article will explain how to form of discrimination against women, the root of the problem, and how Khadijah as the women's agency, which is analyzed using gender perspectives and women's agency theory. There are four arguments against women : first, men are superior and women are inferior: form of gender discrimination is 'subordinated' and the root of the problem is 'class system'. Second, slave women: form of discrimination is 'gender violence' and the root causes are 'patriarchal culture and ideology'. Third and fourth, freedom of opinion only belongs to men, women are considered weak and men are considered strong: the form of gender discrimination is 'stereotipe' and root of the problems are 'patriarchal culture and ideology'.

Keywords: Women Agency, Gender Construction, Novel Khadijah: Ketika Rahasia Mim Tersingkap, Gender Perspective

\section{Abstrak}

Artikel ini menjelaskan tentang kontruksi gender yang terdapat dalam novel Khadijah: Ketika Rahasia Mim Tersingkap karya Sibel Eraslan. Di dalam novel tersebut digambarkan tentang kontruksi gender pada zaman Jahiliyyah yang melekat dan memberatkan wanita. Berkebalikan dengan laki-laki, wanita dalam novel tersebut digambarkan sebagai sosok yang terdiskriminasi. Namun, dalam keadaan tersebut Khadijah hadir sebagai sosok agen perubahan yang memberikan warna baru dan kehidupan yang lebih baik serta berkebasan bagi wanita. Maka, secara lebih spesifik artikel ini akan menjelaskan bagaimana bentuk diskriminasi terhadap wanita yang digambarkan dalam novel tersebut, dan apa akar permasalahannya, serta bagaimana Khadijah sebagai agensi perempuan yang digambarkan dalam novel tersebut, yang dianalisis menggunakan perspektif gender dan teori agensi perempuan. Adapun hasil dari artikel ini yaitu terdapat 4 (empat) diskriminasi terhadap wanita: pertama, laki-laki superior wanita inferior: bentuk diskriminasi gender 'subordinasi' dan akar permasalahannya 'sistem kelas'. Kedua, 
perempuan budak: bentuk diskriminasi 'gender kekerasan' dan akar permasalahannya 'kultur budaya dan ideology patriakal'. Ketiga dan keempat, kebebasan berpendapat hanya milik laki-laki dan perempuan lemah laki-laki kuat: bentuk diskriminasi gender 'stereotipe' dan akar permasalahannya 'budaya dan ideologi patriakal'. Adapun Khadijah sebagai agent of change- Khadijah hadir sebagai perempuan yang berpikiran maju dan memposisikan diri sebagai perempuan yang berkedudukan tinggi di masyarakat sehingga perlahan-lahan ia mampu mematahkan ideologi patriakal yang berkembang.

Kata Kunci: Agensi Perempuan, Kontruksi Gender, Novel Khadijah: Ketika Rahasia Mim Tersingkap, Perpekstif Gender

\section{PENDAHULUAN}

Novel Khadijah: Ketika Rahasia Mim Tesingkap Karya Sibel Eraslan ini bercerita tentang kehidupan Khadijah yang kehadirannya telah ditunggu-tunggu oleh kedua orang tuanya Khuwaylid bin Asad dan Fatimah binti Zaidah hingga cerita perjalanan kehidupannya yang penuh lika-liku mendobrak ideologi patriakal pada zamannya yang ia berjuang mati-matian hingga akhir hayatnya. Khadijah sebagai salah satu perempuan yang hidup pada masa Arab jahiliyyah, kehadirannya memberikan warna dan dinamika baru bagi peradaban Arab. Khadijah Binti Khuwailid dilahirkan di lingkungan yang cukup terpandang dan terhormat, sehingga dia tumbuh dengan karakter akhlak yang terpuji, memiliki sifat yang tegas, penalaran yang tinggi dan mampu menghindari halhal yang tidak terpuji. Sehingga kaumnya pada masa Jahiliyah menyebut dirinya athThahirah (wanita suci) (Hamid, 1995: 41).

Ayah Khadijah yang seorang pedagang mewariskan keahlian dagangnya kepada Khadijah, sehingga menjadikan Khadijah sebagai pedagang yang sukses dan kaya raya. Khadijah menyadari sifat harta yang mengoda untuk hidup bermewah-mewah dan berfoya-foya. Namun, karena kepribadiannya yang agung ia tidak terperangkap sama sekali. Bahkan, ia tidak hanya menikmati hasil jerih payahnya sendiri dan keluarganya, tapi ia juga suka menolong orang lain dengan harta yang ia miliki, seperti orang-orang miskin, anak-anak yatim, para janda, juga orang sakit dan cacat (Amin, 2014: 16-18).

Situasi kehidupan pada masa Khadijah hidup atau Arab Pra-Islam ataupun sebelum Nabi Muhammad memulai tugasnya sebagai Rasulullah berada dipuncak kekacaubalauan, amat sengsara penuh derita. Di permukaannya tidak dijumpai wajah yang layak dibanggakan, segala-galanya mendendam risau gelisah, di mana-mana onar belaka (Bakar, 2008: 8). Hal ini dikarenakan orang-orang Arab terlahir dengan kondisi alam yang kejam, yang melahirkan watak dan sifat yang cenderung keras sehingga perjuangan untuk memperjuangkan hak-hak menjadi lebih besar (Fadil, 2008: 67-68). Selain itu orang-orang Arab hidupnya suka berpindah-pindah tempat (nomaden), mereka suka mengembara ke mana-mana. Mereka juga suka berperang, kaum laki-laki menjadi dominan dalam posisi ini, sehingga ketika mereka memiliki anak laki-laki mereka bangga, tetapi sebaliknya ketika mereka mendapatkan anak perempuan mereka merasakan aib dan malu (Bakar, 2008: 8). 
Perbuatan membunuh bayi-bayi perempuan menjadi suatu perbuatan yang dianggap terhormat. Seseorang yang tidak mau membunuh bayi-bayi perempuan mereka berarti memberi beban kepada masyarakat, karena dianggap telah merusak kepentingan bersama, dan tatanan nilai yang telah ditetapkan masyarakat (Fadil, 2008: 67-68), Hal ini dijelaskan dalam Q.S. an-Nahl [16]: 58-59:

(58) "Dan apabila seseorang dari mereka diberi kabar dengan (kelahiran) anak perempuan, hitamlah (merah padamlah) mukanya, dan Dia sangat marah". (59) "Ia Menyembunyikan dirinya dari orang banyak, disebabkan buruknya berita yang disampaikan kepadanya. Apakah Dia akan memeliharanya dengan menanggung kehinaan ataukah akan menguburkannya ke dalam tanah (hiduphidup) ?. ketahuilah, Alangkah buruknya apa yang mereka tetapkan itu". (Q.S. anNahl [16]: 58-59)

Setiap hari sebuah lubang digali di gurun untuk mengubur bayi perempuan yang tak berdosa. Manusia lebih brutal dan lebih kejam ketimbang hyena (sejenis macan). Yang kuat menindas yang lemah. Kebrutalan dilakukan atas kemanusiaan, kekejaman disetujui, haus darah dipuji, pertumpahan darah dianggap kebaikan, dan perzinahan serta perselingkuhan lebih lazim ketimbang perkawinan yang sah (Gulen, 2002: 3). Dalam kelas bangsawan Arab, seorang laki-laki dianggap pemimpin dalam keluarga. Wanita tidak bisa menentukan pilihannya sendiri melainkan melalui wali. Sedangkan kelas masyarakat lainnya, beraneka ragam dan memiliki kebebasan hubungan antara laki-laki dan wanita. Selain itu, kebiasaan masyarakat Arab jahiliyyah adalah poligami tanpa ada batas maksimal dan tanpa pandang bulu siapa yang akan dinikahinya (Gulen, 2002: 3).

Kontruksi sosial pada zaman Jahiliyyah yang disebutkan di atas menjadikan wanita pada masa itu jauh dari kata bahagia. Wanita hanya bisa menerima apa yang terkontruksi oleh budaya. Namun, dengan adanya Khadijah ia mampu mendobrak sistem partriakal yang mendominasi kontruksi sosial pada masa itu, meskipun tidak sepenuhnya. Khadijah juga memberikan warna dan dinamika baru bagi kehidupan wanita untuk lebih berani lagi dan menentukan jalan arah hidupnya sendiri. Oleh karena itu, artikel ini akan membahas bagaimana kontruksi sosial mengenai gender dalam novel Khadijah: Ketika Rahasia Mim Tesingkap Karya Sibel Eraslan bagaimana bentuk ketidakadilan atau diskriminasi gender dan akar permasalahannya, serta bagaimana Khadijah sebagai agen perempuan dalam mendobrak sistem patriakal dalam novel tersebut.

\section{LANDASAN TEORI}

\section{Gender sebagai Kontruksi dan Agensi Perempuan}

Kesalahan dalam memahami makna gender dan sex adalah penyebab terjadinya bias gender. Gender dan sex adalah dua hal yang berbeda. Selain itu, kontruksi sosial yang bias gender memperparah keadaan dalam memahami gender. Adanya bias gender menciptakan ketidakadilan gender atau diskriminasi maupun penindasan. Ketidakadilan ini dapat terjadi di berbagai bidang kehidupan, baik dalam wilayah 
domestik maupun publik, dalam bidang pendidikan, kesehatan, keamanan, ekonomi, politik, maupun pembangunan secara lebih luas (Rohmaniyah, 2009: 209).

Penggunaan istilah gender belum terlalu lama. Dalam jurnal yang berjudul Gender dalam Perspektif Islam yang ditulis oleh Rusdi Zubeir Shorwalter menyebut bahwa "wacana gender mulai ramai di awal tahun 1977, ketika sekelompok feminis di London tidak lagi memakai isu-isu lama seperti Patriarchal atau sexist, tetapi menggantikannya dengan wacana gender (gender discourse)" (Zubeir, 2018: 104). Lebih lanjut, Shorwalter yang mengartikan gender lebih dari sekedar pembedaan lakilaki dan perempuan dilihat dari konstruksi sosial budaya, tetapi menekankan gender sebagai konsep analisa yang mana kita dapat menggunakannya untuk menjelaskan sesuatu (Zubair, 2018: 104). Pembicaraan mengenai konsepsi gender-pun telah menjadi ideologi. Hal ini tentu melibatkan perjalanan sejarah terbentuknya ideologi tersebut, dengan topangan agama, politik, maupun sosio-kultural (Ernawati, 2010: 128).

Mansour Fakih menyebut bahwa gender adalah suatu sifat yang melekat pada kaum laki-laki maupun perempuan yang dikontruksi secara sosial maupun kultural (Fakih, 2013: 8). Misalnya bahwa perempuan itu dikenal lemah lembut, cantik, emosional atau keibuan. Sementara laki-laki dianggap kuat, rasional, jantan dan perkasa. Ciri dari sifat itu sendiri merupakan sifat-sifat yang dapat dipertukarkan. Artinya ada laki-laki yang emosional, lemah lembut, keibuan, sementara juga ada perempuan yang kuat, rasional, perkasa. Perubahan ciri dari sifat-sifat itu dapat terjadi dari waktu ke waktu (Fakih, 2013: 8-9). Isu gender menjadi agenda penting dari semua pihak, karena realitas perbedaan gender yang berimplikasi pada perbedaan status, peran dan tanggung-jawab antara manusia laki-laki dan perempuan seringkali menimbulkan apa yang disebut dengan ketidakadilan gender atau diskriminasi maupun penindasan (Rohmaniyah, 2013: 57).

Maka di sini, analisis gender merupakan analisis yang digunakan dalam menempatkan posisi setara antara laki-laki dan perempuan untuk mewujudkan tatanan masyarakat sosial yang lebih egaliter. Jadi, gender bisa dikategorikan sebagai perangkat operasional dalam melakukan measure (pengukuran) terhadap persoalan laki-laki dan perempuan terutama yang terkait dengan pembagian peran dalam masyarakat yang dikonstruksi oleh masyarakat itu sendiri (Sa'i, 2015: 122). Pengungkapan masalah kaum perempuan dengan menggunakan analisis gender sering menghadapi perlawanan (resistance), baik dari kalangan kaum laki-laki ataupun kaum perempuan sendiri. Hal ini bisa jadi disebabkan: pertama, mempertanyakan status kaum perempuan pada dasarnya adalah mempersoalkan sistem dan struktur yang telah mapan. Kedua, mendiskusikan soal gender berarti membahas hubungan kekuasaan yang sifatnya sangat pribadi, yakni menyangkut dan melibatkan individu kita masing (Hafid, 2014: 22).

Budaya patriarki menjadi akar permasalahan gender di mana laki-laki mempunyai kedudukan lebih tinggi dari perempuan. Dalam budaya ini, ada perbedaan yang jelas mengenai tugas dan peranan perempuan dan laki-laki dalam kehidupan bermasyarakat, khususnya dalam keluarga. Laki-laki sebagai pemimpin atau kepala keluarga memiliki otoritas yang meliputi kontrol terhadap sumber daya ekonomi, dan 
suatu pembagian kerja secara seksual dalam keluarga. Hal ini menyebabkan perempuan memiliki akses yang lebih sedikit di sector public dibandingkan laki-laki (Subhan, 2015: 8-9).

Analisis gender dalam paper ini akan digunakan sebagai pisau analisis untuk melihat bagaimana resistensi seorang perempuan dalam mendobrak sistem patriakal dengan tujuan mendapatkan hak-haknya sebagai wanita yang harus diperjuangkan. Wanita layak untuk hidup bebas sesuai pilihannya tanpa ada paksaan dan ketergantungan pada pihak lain. Bias-bias gender dan anggapan bahwa wanita itu second sex dianalisis dengan perspektif gender sehingga didapati suatu penjelasan yang tidak bias.

Selain itu, untuk menganalisis agensi perempuan dalam Novel Khadijah: Ketika Rahasia Mim Tersingkap karya Sibel Eraslan, akan digunakan teori Performativity Judith Butler sebagai pisau analisisnya. Judith Butler mendasarkan teorinya pada dua pemikiran Michel Foucault. Pertama, menurut Foucault, kekuasaan tidak dapat dipahami semata-mata pada model dominasi sebagai sesuatu yang dimiliki dan disebarkan oleh individu atau penguasa agen atas orang lain. Sebaliknya, kekuasaan harus dipahami sebagai hubungan kekuatan yang strategis yang menembus kehidupan dan menghasilkan bentuk keinginan, objek, hubungan, dan wacana yang baru (Mahmood, 2006: 45). Kedua, menurut Foucault, subjek tidak mendahului hubungan kekuasaan di dalam bentuk kesadaran individu, tetapi diproduksi melalui hubungan yang membentuk kondisi yang diperlukan dari kemungkinannya. Hal ini dinamakan Foucault dengan paradox subjektivitas yaitu proses dan kondisi yang mengamankan subordinasi subjek, yang berarti ia menjadi identitas dan agen aktif (Mahmood, 2006: $45)$.

Pemahaman tentang kekuasaan dan pembentukan subjek seperti itu mendorong peneliti untuk mengkonseptualisasikan agensi tidak hanya sebagai sinonim untuk penolakan terhadap hubungan dominasi, tetapi sebagai kapasitas untuk bertindak yang menciptakan dan memungkinkan hubungan subordinasi tertentu. Butler menyebut teori agensi dengan "model agensi emansipatoris", yang mengandaikan bahwa semua manusia diberkahi dengan kehendak, kebebasan, dan intensionalitas "yang kerjanya" digagalkan oleh hubungan kekuasaan yang dianggap berada di luar subjek. Sebagai gantinya, Butler menempatkan kemungkinan agensi di dalam struktur kekuasaan (bukan di luarnya) dan, yang lebih penting, menunjukkan bahwa struktur norma yang berulang tidak hanya berfungsi untuk mengkonsolidasikan suatu rezim wacana / kekuasaan tertentu tetapi juga menyediakan sarana untuk destabilisasi (Mahmood, 2006: 46-47).

Dengan kata lain, tidak ada kemungkinan "kehancuran" sosial norma-norma yang tidak tergantung pada "melakukan" norma-norma agensi berada. Oleh karena itu, dalam pengulangan produktif ini. Butler juga menolak dorongan untuk menambat arti agensi bagi teleologi politik emansipatoris yang telah ditentukan sebelumnya. Akibatnya, logika subversi dan resignifasi tidak dapat ditentukan sebelumnya dalam kerangka Butler karena tindakan resignifasi / subversi adalah menurutnya kontingen dan rapuh muncul di tempat yang tak terduga dan berperilaku dengan cara yang tidak 
terduga (Mahmood, 2006: 47). Konsep agensi dalam pemikiran Butler dikembangkan terutama dalam konteks di mana norma dilontarkan atau dikenakan pengunduran diri. Sehingga Konsekuensi analisis tentang kekuatan norma tetap didasarkan pada kerangka kerja agonis, norma yang menekan atau ditumbangkan, ditegaskan kembali atau mengundurkan diri sehingga seseorang dapat merasakan sedikit norma-norma kerja yang dilakukan di luar daftar penindasan dan subversi ini dalam konstitusi subjek. Ia menemukan bahwasanya kemungkinan resistensi terjadi karena normativitas, dan performativitas yang dikonsep dalam hal dualistik struktur konsolidasi atau pengunduran norma. Penjelajahan Butler, pada satu sisi untuk keseluruhan minatnya dalam melacak kemungkinan resistensi kekuatan pengatur normativitas, dan di sisi lain, pada modelnya performativitas yang terutama dikonsep dalam hal dualistik struktur konsolidasi / pengunduran diri norma (Mahmood, 2006: 47-48).

Maka, teori agensi Judith Butler atau dinamakan dengan teori performativity adalah teori yang melihat bahwasanya kekuasaan mempengaruhi agen-agen untuk bertindak, dan norma-norma yang ada juga menjadikan penghambat langkah agen-agen untuk aktif.

\section{HASIL PENELITIAN DAN PEMBAHASAN}

\section{Kontruksi Gender dalam Novel Khadijah: Ketika Rahasia Mim Tesingkap Karya Sibel Eraslan}

Perempuan dalam tradisi patriarkal selalu menjadi second sex. Perempuan ditempatkan dalam ruang domestik yang dibatasi hak-hak dan ruang geraknya sehingga sulit mencapai kemajuan dalam bidang pendidikan, pekerjaan maupun sosial. Namun, tidak sedikit perempuan yang mampu menggugat tradisi partiarkal yang telah mapan dan menundukkan laki-laki sebagai superior dalam tatanan sosial. Meskipun demikian, perempuan-perempuan yang mampu melampaui zamannya justru dianggap menyelisihi sehingga mendapatkan banyak perlawanan dari laki-laki, maupun perempuan yang masih terbelenggu oleh pemikiran patriarkal.

Merujuk kepada sejarah mengenai hubungan antara laki-laki dan perempuan di berbagai belahan dunia, baik pra-Islam maupun masa Islam hingga sekarang, pihak lakilaki selalu dalam posisi dominan, walaupun kaum perempuan juga pernah mengukir sejarah dominasinya (Wijaya, 2004: 134-135). Adanya aturan perbudakan dalam tanah Arab pra-Islam merupakan bentuk dominasi laki-laki dan diskriminasi gender (Wijaya, 2004: 145). Tidak hanya itu pembunuhan terhadap bayi perempuan yang baru lahir serta tidak adanya kebebasan bagi perempuan untuk menentukan dan mengambil pilihan dalam hidupnya menjadikan perempuan terkukung akan keadaan yang ada dan bahkan membenarkan apa yang terjadi serta merasa bangga (Wijaya, 2004: 144-145).

Kehidupan rumah tangga yang menjadikan perempuan sebagai objek sejatinya memang perlu digugat. Superior laki-laki yang menempatkan diri dalam posisi paling berkuasa telah menghasilkan sikap yang sewenang-wenang. Perempuan ditundukkan sehingga hanya mampu menerima, tanpa memberikan perlawanan.

\section{Pria Superior Wanita Inferior}


Relasi antara pria dan wanita dalam kontruksi patriarkal selalu menempatkan perempuan dalam posisi inferior. Wanita dipandang lemah dan dilemahkan dikarenakan identitas dirinya yang perempuan. Keadaan inferior tersebut juga dialami oleh Khadijah selama menikah dengan Atik, yang tampak dalam data berikut.

“....Atik bin Aziz (suami kedua Khadijah) adalah laki-laki Mekah yang keras. Seringkali terlebih di malam hari saat dirinya mabuk, anak-anak maupun yang tua tidak luput dari cercaan, bentakan dan kata-kata kasar. setiap kali Atik kembali ke rumah, ia sembunyikan anak-anaknya ke kamar belakang."(Eraslan, 2012: 26-27)

Sikap Atik terhadap Khadijah adalah bentuk ketidakadilan dari superioritas seorang pria. Hal ini harus ditindaklanjuti dengan tegas, keadilan harusnya menjadi hal yang mendasar dari adanya sebuah pernikahan. Sebab, pernikahan bukan hanya tentang satu pihak, tapi tentang dua pihak yang menjadi satu kesamaan di mata Tuhan (Engineer, 2009: 237-238).

Data di atas menggambarkan tokoh Atik sebagai representasi dari superior. Sikap yang ditunjukkan oleh Atik merupakan bentuk penindasan yang didasarkan pada gender sebagai produk dari patriarkal yang telah mapan. Atik tidak merasa perlu mengormati Khadijah sebagai istri maupun perempuan karena ia berada pada posisi paling kuat sebagai laki-laki yang menjadikannya kepala keluarga. Sikap Atik sesuai dengan pendapat Engineer (2009: 237-238). yang menyatakan bahwa ketidakadilan itu berasal dari struktur sosial yang menyebabkan superioritas laki-laki atas wanita, Selain itu dalam konteks agama, androsentrisme artinya bahwa tradisi-tradisi agama dikontruksi, dikembangkan oleh laki-laki dari perspektif laki-laki, dan oleh karenanya yang menjadi fokus utamanya adalah pengalaman laki-laki (Rohmaniyah, 2008:60).

Annemarie Schimmel (1998: 146) mengungkapkan bahwa wanita merupakan lambang cita-cita tertinggi yang diharapkan dan dirindukan seseorang, dan makna simbolis dari ka'bah tampaknya dikait-kaitkan dengan itu. Perempuan seharusnya memperoleh posisi yang terhormat dihadapan laki-laki, sebagaimana ka'bah yang disucikan oleh ummat. Perempuan patut dihormati, di junjung tinggi, dan perlakukan sesuai dengan hak-haknya serta diberikan kebebesan untuk berkembang sebagaimana laki-laki. Maka, Atik yang tumbuh dalam kebudayaan patriarkal telah mencederai penciptaan Tuhan.

Bentuk diskriminasi gender di atas adalah subordinasi -yaitu anggapan perempuan itu irrasional atau emosional sehingga perempuan tidak bisa tampil memimpin, berakibat munculnya sikap yang menempatkan perempuan pada posisi tidak penting (Fakih, 2013: 15). Subordinasi melandasi pola relasi atau pola hubungan sosial yang hirarkhis di mana salah satu pihak memandang dirinya lebih tinggi dari mereka yang direndahkan, seperti anggapan bahwa perempuan adalah nomor dua (second ses) (Fakih, 2013: 15). Keadaaan tersebut memaksa perempuan sebagai inferior untuk melakukan resistensi demi bertahan atas superioritas laki-laki.

Adapun akar permasalahan dari kontruksi sosial laki-laki sebagai superior dan perempuan sebagai inferior adalah kenyataan bahwa perempuan hanya diberi ruang domestik, menjadikan perempuan tidak dapat menempati sendi-sendi penting dalam 
kelas sosial. Sebagai akibat dari terbatasnya ruang gerak tersebut, perempuan tidak memiliki kesempatan untuk memaksimalkan potensi yang dimiliki sehingga tidak dapat bersaing dengan laki-laki baik dalam ranah ekonomi maupun sosial. Keadaan tersebut menciptakan relasi tuan-budak yang menempatkan perempuan sebagai inferior dan laki-laki sebagai superior sesuai dengan teori feminisme marxisme (Fakih, 2013: 8889).

\section{Perempuan Budak}

Posisi perempuan yang lemah dalam kontruksi patriarkal menghadirkan perempuan sebagai objek. Puncak dari ke-inferior-an perempuan adalah ketika mereka diperdagangkan sebagai budak. Bukan hanya itu, perempuan juga dieksploitasi secara seksual dengan menjadikan mereka sebagai pertunjukkan untuk memperdaya nafsu kepada calon pembeli, seperti dalam data berikut.

"Para majikan dengan keji meludahi, mencaci, bahkan mencambuki budak-budak
dagangannya. Di sana terdapat budak-budak dagangan dari semua usia. Mereka
dijajar untuk dipertontonkan kepada para calon pembeli. Tidak jarang mereka
dipaksa menampilkan berbagai kemampuannya dengan cara dicambuk berkali-
kali. Di saat-saat itulah biasanya dipertontonkan budak wanita yang masih berusia
sepeluh tahunan. Mereka berpakaian terbuka, membagikan minuman keras kepada
para calon pembeli, dan tidak jarang memberikan pertunjukan untuk memerdaya
nafsu syahwat mereka -meminum anggur sambil membaca puisi”. (Eraslan, 2012:
54-55)

Data di atas menggambarkan kepada para pembaca tentang kondisi perempuanperempuan budak pada masa Arab Jahiliyah. Perempuan yang diperdagangkan demi keuntungan ekonomi, juga dieksploitasi secara seksual sebagai bahan promosi.

Terdapat perbedaan perlakuan antara budak laki-laki dan perempuan. Budak laki-laki melakukan atraksi agar menarik minat pembeli. Atraksi tersebut menonjolkan kemampuan mereka, sehingga yang menjadi tolak ukur minat pembeli terhadap mereka adalah kompetensi para budak laki-laki. Berbeda dengan budak perempuan yang harus menunjukkan sensualitas sebagai nilai utama dalam perdagangan. Maka, perempuan mengalami dua kali eksploitasi, yaitu secara kompetensi pribadi dan seksual. Oleh sebab itu, bentuk diskriminasi perempuan sebagai budak dalam Novel Khadijah adalah kekerasan. Kekerasan yang dimaksud adalah serangan atau invasi (assault) terhadap fisik maupun integritas mental psikologis seseorang (Fakih, 2013: 17).

Adapun akar masalah dari diskriminasi gender dalam Novel Khadijah disebabkan kultur budaya beserta ideologi patriarkal. Sehingga, sesuai dengan teori feminis radikal kaum laki-laki secara biologis maupun politis merupakan akar dari permasalahan. Penguasaan fisik perempuan oleh laki-laki seperti hubungan seksual, adalah bentuk dasar penindasan terhadap kaum perempuan (Fakih, 2013: 85).

\section{Kebebasan Berpendapat hanya Milik Laki-laki}

Posisi laki-laki sebagai superior memberi ruang bicara yang lebih luas dibandingkan dengan perempuan. Laki-laki dengan superioritasnya memarjinalkan kebebasan bersuara yang dimiliki oleh perempuan, sehingga relasi yang terbangun adalah relasi menguasai. 
"Perjalanan satu malam itu membuat Khadijah dan Maisaroh mendapatkan pelajaran yang sangat penting: orang-orang Mekah hanya mau mendengarkan suara kaum laki-laki dan berhala-berhala yang disembah untuk meraka. Seolah kota Mekah telah menjadi kotanya berhala kaum laki-laki" (Eraslan, 2012: 26)

Data di atas adalah refleksi perempuan pada masa Arab jahiliyah. Kebudayaan patriarkal yang menempatkan laki-laki dalam posisi yang tinggi menjadikan laki-laki sebagai identitas. Pernyataan, "Seolah kota Mekah telah menjadi kotanya berhala kaum laki-laki." merupakan bukti kuatnya pengaruh laki-laki di Kota Mekah. Hanya laki-laki yang memiliki kekuatan untuk memutuskan, dan mengemukakan pendapat. Perempuan hanya hadir sebagai pelengkap, bagian masyarakat yang pasif dan tidak dominan dengan ruang gerak yang sempit dan terbatas.

Bentuk diskriminasi yang terdapat dalam Novel Khadijah merupakan diskriminasi stereotipe. Stereotipe adalah pelabelan yang digeneralisasi yang dipegang oleh kelompok-kelompok yang sosial berdasarkan sikap prasangka atau kurangnya penilaian kritis (Rohmaniyah, 2008: 24). Diskriminasi ini memandang perempuan sesuai dengan sudut pandang laki-laki, tanpa mempertimbangkan perempuan sebagai subjek yang tunggal. Dalam hal ini, laki-laki memandang perempuan sebagai makhluk yang lemah secara akal, sehingga segala keputusan berada di tangan laki-laki.

Adapun akar permasalahan yang menyebabkan munculnya tendensi laki-laki terhadap perempuan yang dianggap lemah berdasarkan akal adalah feminis radikal yang menempatkan laki-laki sebagai penguasa dan perempuan yang dikuasai. Oleh sebab itu, muncul anggapan bahwa laki-laki memiliki kekuatan akal yang lebih sehingga dianggap mampu melindungi diri maupun orang lain.

\section{Perempuan Lemah Laki-laki Kuat}

Perempuan selain lemah secara akal dalam konstruksi masyarakat, juga ditendensikan dengan lemah secara fisik. Hal tersebut tampak dalam data berikut.

"Tidak tahukah kalian bahwa melakukan perjalanan malam menyusuri jalanan ini sangat berbahaya bagi wanita? Memamg benar, mereka para lelaki telah melampaui batas dalam perbuatan maksiatnya. Namun, kalian sungguh nekat melakukan perjalanan malam tanpa didampingi seorang lelaki!" (Eraslan, 2012: 24)

Data di atas adalah refleksi dari perempuan dengan tendensi lemah secara fisik. Hal tersebut tidak sepenuhnya salah, sebab perempuan memang memiliki konstruksi tubuh yang berbeda dengan laki-laki. Namun, dalam melakukan sebuah perjalanan, lakilaki dan perempuan tidak memiliki banyak perbedaan. Oleh sebab itu, kehadiran lakilaki yang mendampingi perempuan dalam melakukan perjalanan bukanlah sebuah keniscayaan, dan perempuan tidak seharusnya dilarang dalam melakukan perjalanan ketika tidak ada laki-laki yang mendampingi.

Bentuk diskriminasi yang terdapat dalam Novel Khadijah adalah stereotipe. Lakilaki memiliki pandangan subjektif terhadap perempuan sehingga perempuan harus hidup dalam konstruksi sosial sesuai dengan stereotipe laki-laki. Dalam hal ini, perempuan dianggap lemah secara fisik yang secara langsung menyatakan bahwa lakilakilah yang kuat. oleh sebab itu, perempuan dipandang selalu membutuhkan kehadiran 
laki-laki ketika dalam melakukan perjalanan, karena laki-laki dianggap memiliki kekuatan untuk melindungi sedangkan perempuan tidak.

Adapun akar permasalahan yang terdapat dalam Novel Khadijah adalah feminis radikal. Melalui stereotipe perempuan lemah, laki-laki tampil sebagai pelindung sekaligus penguasa perempuan. Maka, dalam kelas sosial laki-laki merupakan superior dan perempuan adalan inferior.

\section{Khadijah sebagai Agensi Perempuan dalam Novel Khadijah: Ketika Rahasia Mim Tesingkap Karya Sibel Eraslan}

Manusia adalah zoon politikon, begitu juga dengan perempuan. Maka, seharusnya perempuan juga diberikan kuasa untuk melakukan relasi sosial dengan orang lain, selama tidak melewati koridor syariah. Namun, kenyataan bahwa perempuan hanya diberikan ruang domestik telah banyak menghalang-halangi perempuan untuk melakukan kontak sosial baik dengan sesama perempuan atau laki-laki.

Generalisasi yang menempatkan perempuan sebagai pelaku nomor dua dalam strata masyarakat telah lama mempasifkan fungsi perempuan dalam relasi. Pendapat dan pandangan perempuan tentang sebuah perkara dianggap remeh, sehingga perempuan hanya tampil sebagai objek pelengkap yang melengkapi laki-laki sebagai subjek. Padahal, banyak perempuan yang pemikirannya maju, dan pertimbangannya matang dalam mengambil keputusan sehingga dapat dirujuk dalam mengambil keputusan.

"Ia tidak akan terburu-buru dalam mengambil keputusan. Semuanya dipikirkan terlebih dahulu, dicari kelemahan dan sumber permasalahannya. Baru kemudian berdiskusi dengan orang yang dipercaya. Orang disekelilingnya sering menyebutnya sebagai ahli tadabur. Seorang yang memiliki basiroh. Tiap masalah dipahami terlebih dahulu sapai ke akar-akarnya, sehingga setiap keputusan yang diambil benar-benar akurat, tepat dan berumur panjang"(Eraslan, 2012: 100)

Data di atas adalah refleksi kecakapan dan kebijaksanaan Khadijah ketika hendak memutuskan sebuah perkara. Ketika perempuan-perempuan lain masih terbelenggu dalam lingkaran kepasrahan terhadap kebudayaan patriarkal, Khadijah telah mampu tampil mengemuka melalui kemampuan mengambil putusan yang akurat, tepat dan berumur panjang.

Khadijah adalah perempuan yang mampu menampilkan diri agar dinilai bukan melalui kacamata gender, malainkan melalui akal. Maka, Khadijah adalah perempuan revolusioner yang mampu mematahkan asumsi bahwa perempuan tak perlu dimintai pendapat. Bahkan sebelum al-Qur'an turun pun ia selalu mengedepankan musyawarah, berpikir dan merenung. Allah berfirman yang artinya: “... dan bermusyawarahlah dengan mereka dalam urusan itu..." (Q.S. Ali Imran (159). Sayyid Quthb menyatakan bahwa bermusyawarah itu bertujuan untuk menetapkan prinsip didalam menghadapi saat-saat kritis, dan untuk memantapkan ketetapan dalam kehidupan serta untuk menggugurkan alasan yang lemah mengenai suatu persoalan (Quthb, 2001: 195).

Berpikir cermat dan hati-hati serta bijaksana dalam mengambil keputusan sejalan dengan perintah Al-quran yaitu, "Maka Apakah mereka tidak memperhatikan 
unta bagaimana Dia diciptakan." (18) "Dan langit, bagaimana ia ditinggikan?" (19) "Dan gunung-gunung bagaimana ia ditegakkan?" (20) Dan bumi bagaimana ia dihamparkan?" Dalam Tafsir al-Mishbah, Quraish Shihab menjelaskan bahwa ayat tersebut mengajak manusia untuk berpikir dan merenung. Melihat konteks ayat tersebut, yang pertama terlintas dalam benak mereka adalah yang terdekat kepada diri mereka, yaitu unta yang mereka tunggangi. Setelah itu, tidak ada lagi yang tampak dengan jelas kecuali langit yang terbentang dan meninggi. Karena itu, seteleh menuntun untuk memperhatikan unta, manusia di ajak memperhatikan langit, dan dari sana mereka menemukan gunung yang merupakan pasak bumi ini agar tidak oleng. Selanjutnya, bumi yang terhampar memudahkan kehidupan manusia (Shihab, 2002: 277). Sebelum Al-quran turun ke dunia, Khadijah dengan akalnya telah lebih dulu berbuat sesuai dengan perintah Allah tersebut.

Pandangan orang-orang terhadap Khadijah merupakan hasil dari kemampuannya dalam melakukan relasi sosial. Ia begitu baik ketika dimintai pertimbangan oleh laki-laki dan perempuan disekelilingnya. Eksistensi Khadijah menempatkannya dalam relasi sosial yang seimbang. Ia adalah perempuan yang mampu berada sejajar dengan laki-laki sehingga suaranya didengar, dan keberadaannya diakui.

"Cukup" kata Khadijah pada suatu pagi tanpa sedikit marah, tanpa berteriak. "Aku pergi sekarang...” (Eraslan, 2012: 29)

Data di atas merupakan bentuk gugatan Khadijah terhadap arogansi Atik. Khadijah sebagai representasi perempuan pada zamannya, dengan berani meninggalkan Atik yang tidak menghormatinya dalam pernikahan. Ketika perempuan lain takut kepada suami-suami mereka, sehingga harus terus menjadi objek laki-laki karena terlahir dalam posisi inferior.

Keberanian Khadijah telah menjadikan dia pionir yang revolusioner. Ia mengukuhkan diri sebagai perempuan pertama yang mampu mengambil sikap tegas atas ketidakadilan yang ia alami. Keputusan Khadijah ini adalah bukti bahwa perempuan bukan sekedar objek yang tidak bersuara, melainkan juga subjek yang dapat berpikir, menimbang, memilih bahkan memutuskan perkara yang berkaitan dengan diri mereka. Kematangan emosional Khadijah tampak dari sikapnya yang tenang ketika menghadapi masalah. Ia tidak sama dengan perempuan pada umumnya yang menangis ketika terluka.

"Seperti apapun sikap sang suami yang melebihi batas dalam memuaskan kenyamanan dan kesenangan Khadijah tetap bersikap dewasa, ia tetap diam dan diam" (Eraslan, 2012: 28)

Diamnya Khadijah adalah tanda bahwa ia memiliki ketenangan jiwa. Ia hadir sebagai perempuan yang mampu mengendalikan emosi dan tekanan, sehingga ia tumbuh sebagai sosok yang kuat dan matang. Keadaan tersebut tentu berbanding terbalik dengan Atik yang arogan dan emosional. Maka, sikap diam Khadijah telah membuktikan bahwa ia jauh lebih unggul dari pada suaminya. Sebagai perempuan yang ditendensikan dengan lemah dan tidak dapat mengendalikan perasaan, Khadijah justru berlaku sebaliknya. Rumahtangga yang dijalani Khadijah bersama Atik telah menempa 
Khadijah menjadi pribadi yang melampui tendensi gender. Khadijah telah menjadi sosok feminin yang lemah lembut, sekaligus maskulin karena mampu mengedepankan logika dan tetap tenang dalam situasi apapun.

Peran perempuan dalam rumah tangga adalah seperti rahmah, "belas kasih", sehingga layak mendapatkan dukungan tak henti-hentinya dari anak-anaknya (Schimmel, 1998: 54). Menyikapi pernyataan Schimmel tersebut, perempuan memang selalu menjadi muara bagi berbagai permasalahan dalam keluarga. Bahkan, perempuan rela membersamai suaminya ketika melakukan perjalanan yang sejatinya bersifat maskulin, sebagaimana tampak dalam data berikut.

"Khadijah mendaki gunung menemani suaminya yang bergetar penuh dengan keingintahuan setelah waktu yang mereka lewati dalam pendakian itu, dia merasakan seakan-akan di setiap langkah ruhnya tercuci bersih dan batinnya bersinar terang. Jalan yang ia lewati bersama suaminya pun sudah menjadi jalan biasa untuk dirinya" (Eraslan, 2012: 246)

Data di atas menggambarkan Khadijah yang sedang menemani Rosul, suaminya, mendaki Gunung Hira. Kegiatan pendakian yang dilakukan oleh Khadijah bersama dengan Rosul merupakan refleksi dari pengakuan diri Khadijah sebagai manusia, tanpa dibatasi oleh tendensi gender. Ia dihadirkan sebagai representasi perempuan yang tunggal, yang sosoknya tidak diikat oleh adat patriarkal yang membelenggu pada masa itu, sehingga di hadapan Sang Nabi ia memiliki kedudukan yang sama sebagaimana para sahabat yang semuanya adalah laki-laki. Itulah sebabnya, Khadijah diperkenankan melakukan pendakian yang merupakan kegiatan yang sejatinya bersifat maskulin.

Sebagai akibat dari pengakuan Rosul kepada Khadijah sebagai pribadi utuh yang melampaui penilaian gender, maka Khadijah dapat menjadi partner nabi secara utuh pula. Sebab, relasi yang terbangun antara Rosul sebagai nabi dan seorang laki-laki dan Khadijah sebagai istri dan seorang perempuan kemudian menjadi relasi yang horizontal, bukan vertikal. Oleh karena itu, secara implisit wanita dalam perkawinan bukanlah sebagai pihak ketiga, melainkan sebagai pihak kedua bersama laki-laki. Adapun yang berada pada pada posisi pertama adalah Tuhan, sebab wujud dari perkawinan itu tidak lain kecuali memikul amanah Allah SWT (Harahap, dkk, 2002: 199-200).

Memberikan kesempatan bagi istri agar setara dengan suami, dan mempercayainya bahwa ia bisa untuk menyeimbangkan logika suami adalah suatu hal menjadikan seorang istri merasa dihormati dan dihargai serta merasakan kebebesan mengekspresikan diri. Qasim amin mengatakan bahwa kebebasan menggiring umat manusia untuk bisa maju dan berjejak pada kebahagiaan. Kebebasan dianggap sebagai salah satu hak manusia yang paling berharga oleh bangsa yang memahami rahasia kesuksesannya. Kebebasan (freedom) di sini memiliki makna sebuah independensi pemikiran, kehendak, dan tingkah laku, selama tidak melebihi batas keabsahan dan mampu memelihara standar moral masyarakat (Amin, 2003: 49).

"Khadijah memang harus mengatur sendiri bisnisnya. Urusan bisnis ini di manamana selalu sama, penuh dengan perusuh. Hal itu memang menjadi tidak mudah bagi seorang janda. Seringkali para pedagang atau karyawan yang diminta mengurusi harta dagangannya justru membuatnya merugi" (Eraslan, 2012: 17) 
Banyaknya perempuan yang hanya diberikan ruang domestik mendorong Khadijah untuk berdagang. Setelah bercerai dengan suaminya, Atik, Khadijah harus menghidupi anak-anaknya yang masih kecil. Sebagai perempuan yang revolusioner yang berpikiran maju, Khadijah tidak menempatkan dirinya sebagai pelaku pasif dalam masyarakat yang mengharapkan bantuan dari orang tuanya.

Perempuan seharusnya terdidik untuk menempatkan dirinya dengan lebih baik, daripada sekedar menjadi "harta milik" yang berharga bagi laki-laki, menjadi teman yang tak serasi sepanjang hidupnya. Ia harus terdidik sebagai individu yang berkecimpung dalam sosial masyarakat, daripada sebagai materi yang dibentuk oleh laki-laki seperti apa yang ia inginkan. Sikap perempuan terdidik memungkinkannya mengidentifikasi makna kebahagiaan dan kesedihan dalam dirinya daripada orang lain (Amin, 2003: 111). Lebih lanjut, Qasim Amin berpendapat bahwa perempuan dapat berkecimpung dalam aktivitas seperti perdagangan, yang membutuhkan keahlian berorganisasi dan manajemen, daripada aktivitas yang menuntut kekuatan atau keberanian fisik. Perempuan juga sangat patut mengejar beberapa profesi yang artistik (Amin, 2003: 110).

Kenyataan bahwa Khadijah telah berdagang dan memperkerjakan laki-laki sebagai karyawannya membuktikan bahwa ia memiliki kedudukan yang lebih tinggi dibandingkan dengan laki-laki. Sebagai seorang janda, ia telah mencapai pengakuan sebagai perempuan terhormat yang memiliki kuasa untuk mengatur hidup dan bisnisnya sendiri tanpa intervensi dari suami sebagai laki-laki maupun masyarakat sebagai pelaku konvensi patriarkal.

"Bagi Khadijah, dengan usahanya yang memegang peranan penting ketika dihadapkan pada sebuah kekerasan, ia memiliki kepribadian kedua, yaitu mengamati sekelilingnya dan setiap saat selalu siap jika harus menjadi saksi. Dengan kepribadian ini, ia akan membusungkan dadanya penuh keberanian. Keberanian yang didengar dari ayahnya ketika masih gadis belia dan kemudian berkembang bersama kehidupan yang penuh dengan kaidah akhlak. Ia tetap bertahan dengan sabar dan pantang menyerah meskipun takut atau saat tertindas." (Eraslan, 2012: 350)

Tampil di publik merupakan prestasi tersendiri bagi perempuan yang suaranya telah banyak dibelenggu. Namun lebih daripada itu, suara Khadijah telah diperdengarkan sebagai saksi yang dipertimbangkan dalam mengambil keputusan. Khadijah bukan lagi sekedar seorang perempuan, sehingga ia pun memiliki kekuatan untuk diperhitungkan. Batas-batas gender yang memberikan kedudukan bagi perempuan dalam strata sosial dalam kebudayaan patriarkal tidak lagi tampak dihadapan peradilan yang menghadirkan Khadijah sebagai saksi. Khadijah telah menjadi manusia seutuhnya, yang tunggal dan tidak terikat pada gender sehingga ia bebas dalam mengekspresikan diri.

"Hal yang menarik perhatian di antara keluarganya adalah keikutsertaan para wanita dalam perkumpulan laki-laki. Rumah Khadijah menjadi sebuah sekolah. Rumah itu ramai dengan para wanita yang belajar agama baru. Bibi Safiyah, Arwa, Umaimah, dan Atikah, anak-anak perempuan sang bibi, Sa'da binti Quraisy dan 
Arwa binti Quraisy, Hamna dan Zainab, serta istri pamannya Abbas, Lubabah, mereka ibarat sekumpulan Lebah yang datang karena ajakan Khadijah. Mereka benar-benar pekerja keras yang tangguh" (Eraslan, 2012: 319).

Bukan hanya menjadikan dirinya sendiri sebagai perempuan yang mandiri, Khadijah juga mempelopori perempuan-perempuan lain untuk belajar. Khadijah membangun daya belajar perempuan-perempuan yang hidup hanya dalam lingkungan domestik, sehingga turut serta dalam menuntut ilmu dapat menjadi sesuatu yang tabu. Keikutsertaan perempuan-perempuan dilingkungan Khadijah dalam perkumpulan lakilaki merupakan refleksi kesetaraan gender yang mulai muncul di tanah Arab. Laki-laki maupun perempuan diberikan hak yang sama dalam menuntut ilmu, sehingga tidak ada lagi ruang diskriminasi yang didasarkan pada jenis kelamin maupun gender.

\section{KESIMPULAN}

Berdasarkan pembahasan di atas dapat disimpulkan bahwa kontruksi gender dalam novel Novel Khadijah: Ketika Rahasia Mim Tersingkap karya Sibel Eraslan di antaranya yaitu: pertama, laki-laki superior wanita inferior, yang mana ketidakadilan atau diskriminasi gender dalam kontruksi ini yaitu subordinasi, yang akar permasalannya menurut teori feminisme Marxis adalah adanya sistem kelas. Kedua, perempuan budak -bentuk ketidakadilan atau diskriminasi gendernya yaitu violence (kekerasan), yang mana menurut teori feminisme radikal akar permasalahannya yaitu kultur budaya dan ideologi patriakal. Ketiga dan keempat, kebebasan berpendapat hanya milik laki-laki dan perempuan lemah laki-laki kuat -bentuk ketidakadilan atau diskriminasi gendernya yaitu stereotipe yang mana akar permasalahannya menurut feminisme radikal adalah budaya dan ideologi patriakal.

Adapun Khadijah sebagai agen aktif atau agent of change, Khadijah hadir sebagai perempuan yang berpikiran maju dan mampu memposisikan diri sebagai perempuan yang berkedudukan tinggi di masyarakat. Gugatan Khadijah dalam upaya memperoleh hak-haknya dalam keluarga banyak dilakukan dengan aksi, dan bukan kata-kata. Khadijah juga menunjukkan bahwa dirinya merupakan wanita yang tangguh dan lemah lembut, sehingga ketika diberikan kebebasan ia tidak melewati batas-batas syariah. Selain itu, dalam lingkungan sosial, Khadijah lebih banyak menampilkan intelektual diri dan kebijaksanaan sehingga masyarakat mengakui keunggulan yang dimilikinya. Melalui pengakuan tersebut, Khadijah telah mematahkan kebudayaan patriarkal yang hanya menempatkan perempuan dalam ruang domestik sehingga suaranya dapat didengar oleh laki-laki maupun perempuan tanpa mengenal gender. 


\section{DAFTAR PUSTAKA}

Amin, Muhammad Rusli. (2014). Ibu: Kisah Inspiratif Khadijah Wanita Mulia Penghuni Surga. Jakarta: AMP Press.

Amin, Qasim. (2003). Sejarah Penindasan Perempuan: Menggugat Islam Laki-laki, Menggurat "Perempuan Baru". Terj. Syariful Alam. Yogyakarta: IRCiSod.

Bakar, Istianah Abu. 2008. Sejarah Peradaban Islam. Malang: UIN-Malang Press.

Emawati. (2010). Gender dan Islam, YINYANG: Pusat Studi Gender STAIN Purwokerto. Vol. 5. No. 1. Jan-Jun. Dalam http://moraref.kemenag.go.id/ documents/article/97406410605826408/download.

Engineer, Asghar Ali. (2009). Islam dan Teologi Pembebasan, terj. Agung Prihantoro. Yogyakarta: Pustaka Pelajar.

Eraslan, Sibel. (2012). Khadijah: Ketika Rahasia Mim Tersingkap, terj. Ahmad Saefudin dkk. Jakarta: Kaysa Media.

Fakih, Mansour. (2013). Analisis Gender dan Transformasi Sosial. Yogyakarta: Pustaka Pelajar.

Fu’adi, Imam. (2011). Sejarah Peradaban Islam. Yogyakarta: Teras.

Gulen, M. Fethullah. 2002. Versi Terdalam: Kehidupan Rasul Allah Muhammad Saw. Jakarta: PT RajaGrafindo Persada.

Hafid, Mohamad. (2014). Islam dan Gender. Islamuna. Vol. 1. No. 1 Juni. Dalam http://moraref.kemenag.go.id/documents/article/97406410605892247/.

Hamid, Muhyidin Abdul. (1995). Wanita-wanita Shalihah dalam Lintas Sejarah Islam. Terj. Kathur Suhardi. Jakarta: Pustaka al-Kautsar.

Harahap, Rustam Dahar Karnadi Apollo, dkk. (2002). Bias Jender dalam Pemahaman Islam. Yogyakarta: Gama Media.

Khoiriyah. (2012). Reorientasi Wawasan Sejarah Islam: Dari Arab Sebelum Islam hingga Dinasti-dinasti Islam. Yogyakarta: Teras.

Mahmood, Saba. (2006). Feminist Theory, Agency, and the Liberatory Subject: Some Reflections on the Islamic Revival in Egypt. Temenos. Vol. 2. No. 1.

Quthb, Sayyid. (2001). Tafsir Fi Zhilalil Qur'an: Di bawah Naungan al-Qur'an (Surah Ali Imran - an-Nisa' 70). Terj. As'ad Yasin, dkk. Jakarta: Gema Insani Press.

Rohmaniyah, Inayah. (2009). Gender dan Kontruksi Perempuan dalam Agama. Jurnal Studi Ilmu-ilmu al-Qur'an dan Hadits. Vol. 10. No. 2. Juli. 
------. (2013). Gender Androsentrisme dan Sexisme dalam Tafsir Agama. Welfare. Jurnal Ilmu Kesejahteraan Sosial. Vol. 2. No. 1. Juni.

------. (2008). Meninjau Ulang Wacana Spritualitas dan Perempuan. Musawa. Vol. 6. No. 2. Juli.

------. (2014). Kontruksi Patriarki dalam Tafsir Agama: Sebuah Jalan Panjang. Yogyakarta: Fak. Ushuluddin dan Pemikiran Islam UIN Sunan Kalijaga Yogyakarta.

Sa'i, Mad. (2015). Pendidikan Islam dan Gender. Islamuna. Vol. 2. No. 1. Juni. Dalam http://moraref.kemenag.go.id/documents/article/97406410605892182/ download.

Schimmel, Annemarie. (1998). Jiwaku adalah Wanita: Aspek Feminin dalam Spritualitas Islam. Terj. Rahmani Astuti. Bandung: Mizan.

Shihab, M. Quraish, (2002). Tafsir al-Mishbah: Pesan, Kesan, dan Keserasian al-Qur'an. Jakarta: Lentera Hati, 2002.

SJ, Fadil. (2008). Pasang Surut Peradaban Islam dalam Lintasan Sejarah. Malang: UINMalang Press.

Subhan, Zaitunah. (2015). Al-Qur'an dan Perempuan: Menuju Kesetaraan Gender dalam Penafsran. Jakarta: Prenadamedia Group.

Wijaya, Aksin. (2004). Menggugat Otensitas Wahyu Tuhan: Kritik Atas Nalar Tafsir Gender. Yogyakarta: Safiria Insania Press.

Zubeir, Rusdi. (2018). Gender dalam Perspektif Islam. An Nisa'a, Vol. 7, No. 2. Dalam http://jurnal.radenfatah.ac.id/index.php/annisa/article/view/847. 